\title{
MODIFIED WATER-CEMENT RATIO LAW FOR COMPRESSIVE STRENGTH OF RICE HUSK ASH CONCRETE
}

\author{
M. Abdullahi 1,; G. O. Ojelade', and S. M. Auta ${ }^{3}$ \\ 1,3 Civil EngineEring DePartment, Federal University of TeChnology, Minna, NigER STATE. NigERIA

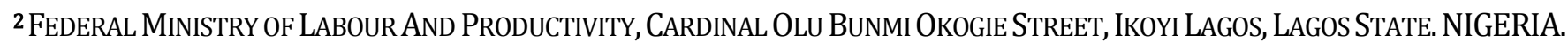 \\ E-mailaddresses:1abdulapai@yahoo.com, 22daddyk67@yahoo.com, ${ }^{3}$ samuel.auta@futminna.edu.ng
}

\begin{abstract}
This work examines the modification of age long water - cement ratio law of Ordinary Portland Cement (OPC) concrete to cater for concrete with Rice Husk Ash (RHA). Chemical analysis of RHA produced under controlled temperature of $600^{\circ} \mathrm{C}$ was carried out $A$ total of one hundred and fifty (150) RHA concrete cubes at five different water/binder ratios and at six replacement levels of RHA $(5 \%, 10 \%, 15 \%, 20 \%, 25 \%, 30 \%)$ were produced with specific attention given to cement/water (c/w) content and RHA/water $(r / w)$ content. The cubes were subjected to compressive strength test at 56 days of curing producing a compressive strength in the range of $3.77 \mathrm{~N} / \mathrm{mm}^{2}$ to $34.04 \mathrm{~N} / \mathrm{mm}^{2}$. A linear polynomial model was fitted into the experimental data using Minitab Package and was found adequate with an adjusted coefficient of determination of $73.0 \%$.Test results show that the compressive strength of hardened RHA concrete depends on cement/water content by weight on one part and RHA/water content by weight on the other part This indicates that the model equation is suitable to evaluate the compressive strength of RHA concrete at $95 \%$ confidence interval and the linear model has the capability of explaining the variability in the data by $73 \%$.
\end{abstract}

Keywords: water-cement ratio, compressive strength, rice husk ash, model.

\section{INTRODUCTION}

Concrete is the most widely used construction material for various types of structures due to its structural stability and strength [1]. It has attained the status of a major building material in modern construction technology. Concrete is the best material of choice where strength, durability, imperviousness, fire resistance and absorption resistance are required. It is a composite material that could be used solely or possibly with other materials depending on the design, quality requirement and cost of construction.

The most common form of concrete nowadays consists of water, cement, and fine aggregate and coarse aggregate. Cement and water form a paste that coat particles of fine and coarse aggregate, hardens and gain strength through a chemical reaction called hydration. A properly designed concrete mix will possess the desired workability for fresh concrete and the required durability and strength for the hardened concrete. The widely used cement is Ordinary Portland Cement (OPC).Concrete is brittle and weak in tension but its compressive strength is about ten to thirteen times greater than its tensile strength [2]. However Mosley and Bungey [3] found the compressive strength to be about eight times greater than the tensile strength.

The most costly input into the production of concrete is cement. Rao et al [1] opined that in the milling of paddy, about
$78 \%$ of the weight is received as rice, broken rice and bran, the rest $22 \%$ is received as husk. The husk of rice is generally considered as a waste product and this over $20 \%$ by weight of rice is quite large and thus constitutes environmental nuisance. Several research efforts have been made to utilise waste materials in construction works $[4,5,6]$. Burnt Rice Husk (RH) produces Rice Husk Ash (RHA). Small quantity of RHA has been used as pozzolans with some degree of successes [7]. Apart from successful usage of small quantity of RHA without sacrificing the strength of mortar, it was noted that proper consumption of RHA contributes in solving environmental pollution [8]. Rice husk ash (RHA) is generated by burning rice husk; on burning, cellulose and lignin are removed leaving behind silica ash. For amorphous silica the burning temperature should be from 500 to $700^{\circ} \mathrm{C}$ [9]. Partial replacement of cement with RHA will greatly assist in reducing the carbon dioxide emission into the environment, reduce the solid agricultural waste (rice husk) and also produce more sustainable cheaper concrete products.

To this end, studies on the development of modified watercement ratio law for concrete incorporating RHA is timely and justifiable. The relationship between the compressive strength and the cement-water ratio is approximately linear in the range of cement-water ratios between about 1.2 and 2.5. The compressive strength is therefore directly proportional to

* Corresponding author tel: $+234-816-741-5678$ 
cement-water ratio [9]. In other words, the compressive strength increases with a decrease in water-cement ratio. High value of water-cement ratio results in greater pore spaces in the hardened concrete leading to lower compressive strength. This is possible since normal concrete fails mainly within the mortar phase.

\subsection{Development of Water/Cement Ratio Law}

Abram found out that for a full compaction at a given age and normal temperature, the strength of concrete is inversely related to the water- cement ratio [9]. This rule was found to fit into the relation

$$
S=\frac{A_{0}}{B_{0}{ }^{\mathrm{x}}}
$$

Where $\mathrm{S}$ is the strength of concrete $\left(\mathrm{N} / \mathrm{mm}^{2}\right), \mathrm{A}_{0}$ and $\mathrm{B}_{\mathrm{o}}$ are empirical constant and $x$ is the water/cement ratio.

Popovics (1998) provided values for $A_{0}$ and $B_{0}$ such that $B_{0}>1$, $\mathrm{A}_{0}=96.5266 \mathrm{MPa}$.However if OPC and Pozzolans [10] are to be used, then the "cement" in water- cement ratio changes to "binder" so that it is now termed water/ binder ratio. For this purpose, Hedegaard and Hansen [11] had earlier considered the modification of Abram's law to suit replacement of cement with fly ash (FA). They started with Bolomeys equation which was based purely on empirical basis but also similar to Abram's law. The equation is given as:

$$
S=A \frac{c}{w}+E
$$

Where $\mathrm{S}$ is the Strength of concrete, $\mathrm{c}$ is the Cement content, $\mathrm{w}$ is the Water content of concrete, and $\mathrm{A}$ and $\mathrm{E}$ are constants for given material, age and curing condition of concrete.

Hedegaard and Hansen [11] observed that during hydration of Portland cement in concrete, crystalline calcium hydroxide is formed as well as cement gel. However this calcium hydroxide will react with fly ash a pozzolans in concrete to produce a colloidal gel similar in structure and properties to the gel formed when Portland cement hydrates. It therefore suggest that the strength development of Portland Cement when FA is added is due to the pore - filling mechanism caused by hydration of Portland cement plus the pore - filling mechanism caused by reaction between FA, water and the calcium hydroxide. Hedegaard and Hansen [11] therefore presented the relation

$$
S=A \frac{c}{w}+B \frac{f}{w}+E
$$

In (3), $\mathrm{S}$ is the Compressive strength of concrete $\left(\mathrm{N} / \mathrm{mm}^{2}\right), \mathrm{c}$ is the Cement content in the concrete $\mathrm{f}$ is the Fly ash content in the concrete, $\mathrm{w}=$ Water content in the concrete and $\mathrm{A}, \mathrm{B}$, and $\mathrm{E}$ are constant for given material, age and curing condition of concrete. Premise on Hedegaard and Hansen [11] observation, this paper seeks to provided response of equation (3), by using rice husk ash as a substitute for fly ash. Thus the target equation is:

$$
\mathrm{f}_{\mathrm{cu}}=A \frac{c}{w}+B \frac{r}{w}+E
$$

Where $\mathrm{f}_{\mathrm{cu}}=\mathrm{S}=$ Compressive strength of concrete. $\mathrm{r}$ is the rice husk ash and other parameters are as defined in (3).

\section{MATERIALS AND METHODS}

\subsection{Material}

The materials used for this work are rice husk, cement, fine aggregate, coarse aggregate, water. For the purpose of this work, the mix ratio used was 1: 1.5:3. Ordinary Portland cement (OPC) of grade $42.5 \mathrm{~N}$ and Rice Husk Ash(RHA) were used at combination levels of 95/05, 90/10, 85/15, 80/20, $75 / 25$ and70/30 of OPC/RHA. These were used at water/binder ratios of $0.4,0.45,0.5,0.55$ and 0.6 respectively. The independent variables in this study are cement/water (c/w) and RHA/water (r/w) ratios by weight. The measured response obtained from the experiment is the compressive strength $\left(f_{\mathrm{cu}}\right)$ at 56 days of curing. Several researchers have monitored compressive strength of concrete at 56 days containing pozzolana $[9,11]$. On this bases, the current research considered the strength of concrete at 56 days bearing in mind that the pozzolanic activity leads to low strength at lower ages with resultant high strength at greater ages.

\subsubsection{Rice Husk Ash (RHA)}

Rice husk, a by- product in the rice milling operation, is available as environmental waste in Minna, Niger State. The rice husk was burnt into ash in batches using a perforated platform having several holes of a size too small for rice husk to penetrate. This was placed on an enclosed floor slab. The slab separates the entire incinerator horizontally into two. The lower chamber is the source of heat heat and hot charcoal can be fed through the opening as indicated in Figure 1. The upper chamber has a compartment for inserting the rice husk for incineration. On top of the upper chamber, is a hollow platform in form of chimney where black smoke can escape during incineration. A cone of rice husk is formed around the chimney to completely cover the hollow platform. The rice husk at the small holes was ignited to incinerate it into rice husk ash (RHA) at $600^{\circ} \mathrm{C}$. The temperature was measured using a thermopile. The ash obtained was allowed to cool for a period of time before being grinded into fine particles.

\subsubsection{Cement}

Ordinary Portland Cement (OPC) of grade $42.5 \mathrm{~N}$ available in Nigerian market was used.

\subsubsection{Fine Ag Ngregates (Sand)}

River sand obtained from Rafin Yashi at Bosso, Minnawas used. The sand was properly sieved and air dried to create no room for any organic/deleterious materials as well as removing the excess water on the surface of the soil particles. 


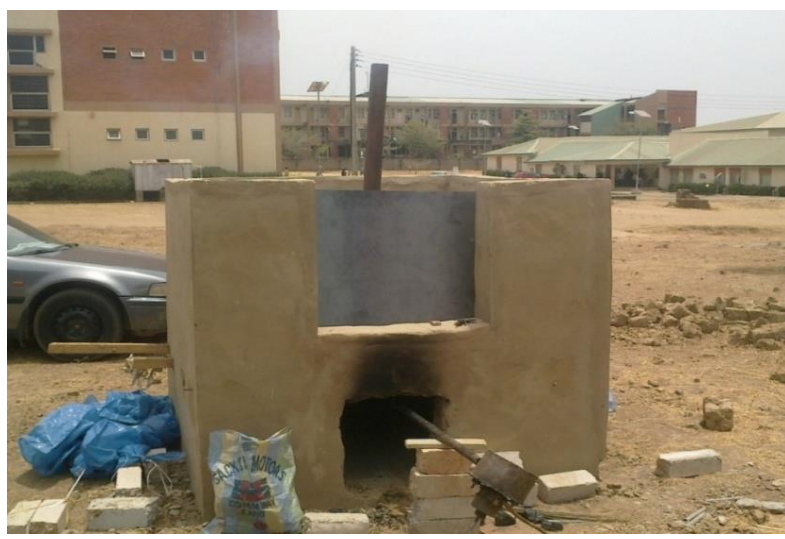

Figure 1: Brick wall Incineration chamber

\subsubsection{Coarse Aggregates}

Crushed granite rock popularly called chipping, purchased from commercial producers in Minna, Niger State was used. The maximum size of the aggregate was $20 \mathrm{~mm}$.

\subsubsection{Water}

The water used was potable drinking water from the Civil Engineering Laboratory, Federal University of Technology (FUT) Minna. The water is suitable for construction work [12].

\subsection{Methods}

Various tests were carried out on each major constituent material of the concrete as well as the fresh and hardened concrete in accordance with relevant British Standards. Materials tested are RHA, fine aggregates (sand) and coarse aggregates. The properties of the materials tested include oxide composition of the RHAin accordance with BS 4550: Part 21978 [13], sieve analysis, moisture content, specific gravity and aggregate impact value.

\subsubsection{Mix Design}

The mix design used for this work was based on Absolute Volume Method. The air content used was two percent (2\%)[13]. The maximum size of the coarse aggregate used was $20 \mathrm{~mm}$. Each item or material constituting the concrete was finally obtained by weight $(\mathrm{kg})$.Specific gravity of materials used were as obtained from the test experiments carried out on such materials before use and are listed in Table 1.

Table 1: Specific gravitie of constituent materials of concrete

\begin{tabular}{lc}
\hline Constituent of concrete & Specific gravity \\
\hline Ordinary Portland Cement $(G c)$ & 3.15 \\
Rice husk ash $(G r)$ & 2.13 \\
Fine aggregate $(G \AA)$ & 2.66 \\
Coarse aggregate $(G s)$ & 2.86 \\
Water $(G W)$ & 1.00 \\
\hline
\end{tabular}

If $\mathrm{W}$ is the weight, $\mathrm{V}$ is the volume and b, c, r, f, s \& w represent binder, cement, RHA, fine aggregate, coarse aggregate and water respectively.
Then, weight of binder $=W_{b}$, Weight of cement $=W_{c}$, Weight of RHA $=W_{r}$, Weight of fine aggregate $=W_{f}$, Weight of coarse aggregate $=W_{s}$ and Weight of water $=W_{w}$. Required mix ratio $=1: 1.5: 3$. Then,

$$
\frac{W_{b}}{W_{f}}=\frac{1}{1.5} ; \quad W_{f}=1.5 W_{b}
$$

Also,

$$
\frac{W_{b}}{W_{s}}=\frac{1}{3} \text { or } \quad W_{s}=3 W_{b}
$$

If water/binder ratio $(\mathrm{w} / \mathrm{b})=z$, then,

$$
W_{w}=z W_{b}
$$

But binder $(\mathrm{b})=\operatorname{cement}(\mathrm{c})+\mathrm{RHA}(\mathrm{r})$

$$
b=c+r
$$

From $1 ; 1.5 ; 3 \quad \mathrm{~b}=1$, Then $c+r=1$. That is $c=1-$ $r$ and $r=1-c$. Here, $r$ and $c$ are fractions of 1

$$
\text { From } \begin{aligned}
b & =c+r \text { then } b=c W_{b}+r W_{b} \\
& =(1-r) W_{b}+(1-c) W_{b}
\end{aligned}
$$

Thus

$$
W_{c}=c W_{b}
$$

and:

$$
W_{r}=r W_{b}
$$

From Absolute Volume Method

$$
V_{b}+V_{f}+V_{s}+V_{w}+V_{a}=1 m^{3}
$$

Since allowable $V a=0.02 m^{3}$

$$
\begin{array}{r}
V_{b}+V_{f}+V_{s}+V_{w}=1-0.02=0.98 \\
\text { But } \quad V_{b}=V_{c}+V_{r} \\
\therefore \quad V_{c}+V_{r}+V_{f}+V_{s}+V_{w}=0.98 \\
\text { From } \quad \text { Density }=\frac{\text { Mass }}{\text { Volume }}=\frac{\text { Weight }}{\text { Volume }}
\end{array}
$$

Where density $=\rho$ and weight $=\mathrm{w}$,

$$
\rho=\rho w * G
$$

Thus,

$$
V=\frac{W}{\rho_{w} \times G}=\frac{W}{1000 \times G}
$$

Substituting for the volumes in (12) gives

$$
\frac{1}{1000}\left(\frac{W_{c}}{G_{c}}+\frac{W_{r}}{G_{r}}+\frac{W_{f}}{W_{f}}+\frac{W_{s}}{G_{s}}+\frac{W_{w}}{G_{w}}\right)=0.98
$$

Substituting (5), (6), (7), (8), \& (9) into 14 gives:

$$
\begin{gathered}
\frac{1}{1000}\left(\frac{c W_{c}}{G_{c}}+\frac{r W_{r}}{G_{r}}+\frac{1.5 W_{f}}{W_{f}}+\frac{3 W_{s}}{G_{s}}+\frac{z W_{w}}{G_{w}}\right) \\
=0.98 \\
\therefore W_{b}=\frac{980}{\frac{c}{G_{c}}+\frac{r}{G_{r}}+\frac{1.5}{G_{f}}+\frac{3}{G_{s}}+\frac{z}{G_{w}}} \\
\text { If } \quad \frac{c}{G_{c}}=K_{1}, \frac{r}{G_{r}}=K_{2}, \frac{1.5}{G_{f}}=K_{3}, \frac{3}{G_{s}}=K_{4}, \frac{Z}{G_{w}}=K_{5}
\end{gathered}
$$

Then:

$$
W_{b}=\frac{980}{K_{1}+K_{2}+K_{3}+K_{4}+K_{5}}
$$

Equation (17) was used to arrive at the value for $W_{b}$ which was also used to compute the remaining quantities. 


\subsubsection{Production of Concrete}

For the purpose of this work, one hundred and fifty numbers of OPC+RHA concrete cubes were produced. Materials quantities for each set were measured separately as obtained from the mix design with the aid of an electronic weighing balance. The cement and rice husk ash (RHA) were mixed thoroughly before fine and coarse aggregates were introduced and also mixed together to obtain a homogenous mixture. The measured quantity of water was then added followed by thorough mixing to obtain a workable concrete. Slump test was conducted on the fresh concrete before placement in $150 \mathrm{~mm} \mathrm{x}$ $150 \mathrm{~mm} \times 150 \mathrm{~mm}$ metal moulds. The concrete in the moulds was tamped severally to acquire maximum compaction for expulsion of air voids. The concrete cubes were removed from the mould after 24 hours and subsequently cured in a curing tank at $25^{\circ} \mathrm{C}$ with potable water.

\subsubsection{Slump test}

This test was carried out on all the mixes used for this work. It was used to determine the workability of the $\mathrm{w} / \mathrm{b}$ ratios adopted for each mix. The slump test was conducted in accordance with BS 1881: Part 102 [15].

\subsubsection{Compressive Strength Test}

The compressive strength of the cube samples was obtained in accordance with the standard procedure given in BS 1881: Part 116 [16]. The samples were allowed to drain off before their weight were taken and recorded. This was followed by the crushing of the cubes. Five samples were crushed each for $\mathrm{w} / \mathrm{b}$ ratio of $0.4,0.45,0.5,0.55$ and 0.60 at each replacement levels of $5 \%, 10 \%, 15 \%, 20 \%, 25 \%$ and $30 \%$ at $56^{\text {th }}$ day of curing using the compressive testing machine in the Concrete Laboratory of Civil Engineering Department, Federal University of Technology, Minna. The test was conducted at loading rate within the range of $0.2 \mathrm{~N} / \mathrm{mm}^{2} / \mathrm{s}$ to $0.4 \mathrm{~N} / \mathrm{mm}^{2} / \mathrm{s}$.

\section{RESULTS AND DISCUSSION}

\subsection{Physical Properties of the constituent materials}

Table 2 shows the physical properties of the constituent materials. The specific gravity of sand was found to be 2.66 which is marginally higher than 2.64 obtained by Oyetola and Abdullahi [17] but still within the range for natural aggregates of 2.6 and 2.7 as reported by Neville [9].The mean specific gravity of RHA was found to be 2.13 , a value very close to that obtained by $[17,18,19]$. The value thus obtained is within 1.9 and 2.4, a range for pulverized fuel ash (PFA) as reported by Neville [9]. However, the value obtained in this work is less than the value of 3.15 for Ordinary Portland Cement (OPC). This shows that RHA is lighter than cement.

Table 1: Physical Properties of the Constituent Materials

\begin{tabular}{cc}
\hline Properties & Experimental value \\
\hline Fineness modulus of sand & 2.98 \\
Fineness modulus of RHA & 0.73 \\
\hline
\end{tabular}

\begin{tabular}{lc}
\hline \multicolumn{1}{c}{ Properties } & Experimental value \\
\hline Moisture content of sand & 1.75 \\
Moisture content of coarse aggregate & 1.25 \\
Specific gravity of sand & 2.66 \\
Specific gravity of coarse aggregate & 2.86 \\
Specific gravity of RHA & 2.13 \\
Aggregate impact value of coarse & $10.75 \%$ \\
aggregate &
\end{tabular}

\subsection{Chemical Analysis of Rice Husk Ash (RHA)}

Table 3 shows the chemical composition of rice husk ash (RHA). The total percentage composition of silicon dioxide $\left(\mathrm{SiO}_{2}\right)$, aluminium oxide $\left(\mathrm{Al}_{2} \mathrm{O}_{3}\right)$ and iron oxide $\left(\mathrm{Fe}_{2} \mathrm{O}_{3}\right)$ was found to be $70.11 \%$, a little higher than recommended minimum value of $70 \%$ for pozzolans by [20]. The value is lower than $73.15 \%$ obtained by [17], 73.56\% obtained by [21], and $89.45 \%$ by [19] but slightly higher than $69.96 \%$ obtained by [22]. However the loss on ignition (LOI) of 13.33 is lower than $17.78 \%$ obtained by [17], $17.78 \%$ of [21] and $18.25 \%$ of [22]. This means that the RHA contains little unburnt carbon which tends to reduce the pozzolanic activity of the ash. However the ash is more effective than that obtained by [17, $21,22]$. It is good to mention that the LOI is higher than $5.81 \%$ by [19] and fairly close to $12 \%$ maximum recommended by [20]. This variation might be due to method of preparation and species of the rice husk. The chemical composition show that the RHA can be classified as Class F Pozzolana. This confirms that the rice husk ash (RHA)used in this work is a good pozzolan.

Table 3: Chemical Composition of Rice Husk Ash (RHA)

\begin{tabular}{lc}
\hline Oxide compounds & Oxide composition (\%) \\
\hline $\mathrm{SiO}_{2}$ & 68.28 \\
$\mathrm{Al}_{2} \mathrm{O}_{3}$ & 1.28 \\
$\mathrm{Fe}_{2} \mathrm{O}_{3}$ & 0.54 \\
$\mathrm{TiO}_{2}$ & 0.07 \\
$\mathrm{CaO}$ & 0.37 \\
$\mathrm{MgO}$ & 3.59 \\
$\mathrm{MnO}$ & 0.13 \\
$\mathrm{~K}_{2} \mathrm{O}$ & 3.14 \\
$\mathrm{Na}_{2} \mathrm{O}$ & 3.78 \\
$\mathrm{P}_{2} \mathrm{O}_{5}$ & 0.16 \\
$\mathrm{SO}_{3}$ & 0.61 \\
$\mathrm{LOI}$ & 13.33 \\
\hline
\end{tabular}

\subsection{Slump of Concrete}

Result of slump test in Table 4 shows that increase in replacement level of cement with RHA leads to decrease in the slump value for all levels of $\mathrm{w} / \mathrm{b}$ ratio. This resulted in decrease in the workability even up to dry mixed concrete because of the absorptive cellular nature character of RHA particles. Reduction in workability causes compaction to be difficult thus leading to creation of air voids in the cubes, the cumulative resultant effect of which is reduction in the strength of the concrete. 
Table 4: Slump for Concrete with $w / b$ Ratios at Different RHALevels (mm)

\begin{tabular}{ccccccc}
\hline $\begin{array}{c}\text { w/b } \\
\text { ratio }\end{array}$ & $5 \%$ RHA & $10 \%$ RHA & 15\%RHA & 20\%RHA & $25 \%$ RHA & $30 \%$ RHA \\
\hline 0.4 & 25 & 10 & 10 & 5 & - & - \\
045 & 30 & 20 & 10 & 5 & - & - \\
0.50 & 35 & 20 & 10 & 5 & - & - \\
0.55 & 85 & 50 & 15 & 10 & - & - \\
0.60 & 140 & 120 & 35 & 25 & 20 & 10 \\
\hline
\end{tabular}

\subsection{Densities of Hardened Concrete}

The density of RHA concrete was investigated as the ratio of the weighted mass of the concrete cube to the volume of the concrete cube [23]. From Table 5, for each $\mathrm{w} / \mathrm{b}$ ratio the density decreases with increases in percentage RHA. However all the densities fall within the range of $2062.81 \mathrm{~kg} / \mathrm{m}^{3}$ and $2572.44 \mathrm{~kg} / \mathrm{m}^{3}$ irrespective of the compressive strength value which indicates that concrete produced with cement replaced with up to $30 \%$ rice husk can be classified as heavyweight concrete. The result was also in tandem with values obtained by [24].

Table 5:Average Densities $\left(\mathrm{kg} / \mathrm{m}^{3}\right)$ of the Hardened Concrete Cubes

\begin{tabular}{ccccccc}
\hline \multicolumn{6}{c}{ Replacement level with rice husk ash } \\
\hline w/b & $5 \%$ & $10 \%$ & $15 \%$ & $20 \%$ & $25 \%$ & $30 \%$ \\
0.40 & 2439.74 & 2296.30 & 2296.90 & 2187.90 & 2149.90 & 2103.72 \\
0.45 & 2572.44 & 2357.93 & 2335.41 & 2327.11 & 2262.52 & 2144.00 \\
0.50 & 2461.63 & 2454.92 & 2376.89 & 2265.48 & 2170.07 & 2131.55 \\
0.55 & 2572.44 & 2556.44 & 2526.83 & 2272.59 & 2062.81 & 2199.11 \\
0.60 & 2495.41 & 2495.41 & 2429.63 & 2435.56 & 2268.44 & 2160.59 \\
\hline
\end{tabular}

\subsection{Compressive Strength of Concrete}

Table 6 shows the experimental data for the compressive strength of concrete. The experimental data obtained in this work was used to develop empirical model for compressive strength of RHA concrete at 95\% Confidence Interval to find the line of best fit. The developed model is presented as equation 18. The output of the regression analysis gave standard deviation of 4.545 , coefficient of determination of $74.8 \%$ and Adjusted coefficient of determination of $73.0 \%$. This implies that the developed model has the ability to explain the variability in the experimental data by $73.0 \%$. Also, the $\mathrm{P}$ values for the independent variables $\mathrm{c} / \mathrm{w}, \mathrm{r} / \mathrm{w}$ as well as the constant $\mathrm{E}$ are $0.024,1.47 \times 10^{-9}$, and $1.95 \times 10^{-8}$ respectively. These three $\mathrm{P}$ values are all less than 0.05 as shown in Table 7 , an indication that there is significant relationship between the Independent variables and the response which is the compressive strength $\left(\mathrm{f}_{\mathrm{cu}}\right)$.

$$
\mathrm{f}_{\text {cu }}=-7.026 \frac{\mathrm{c}}{\mathrm{w}}-42.467 \frac{\mathrm{r}}{\mathrm{w}}+45.305
$$

Where $\mathrm{A}=-7.026$ and $\mathrm{B}=42.467$ and $\mathrm{E}=45.305$
Whereas Hildegard and Hansen [11] obtained 32.62, 7.67 and -16.63 for A, B and E respectively forfly ash producing the model equation indicated as Equation 19.

$$
\mathrm{f}_{\text {cu }}=32.62 \frac{c}{w}+7.67 \frac{f}{w}-16.63
$$

The predicted response for new compressive strength of fly ash (FA) concrete by [11] are in the range of $2.17 \mathrm{~N} / \mathrm{mm}^{2}$ and $32.11 \mathrm{~N} / \mathrm{mm}^{2}$ as against $1.16 \mathrm{~N} / \mathrm{mm}^{2}$ and $30.81 \mathrm{~N} / \mathrm{mm}^{2}$ obtained for RHA from Equation 18. The closeness in the range of values produced by these two models indicated that the model equation for RHA is suitable for use in estimating the compressive strength of Rice Husk Ash (RHA) concrete.

Table 6: Compressive Strength of Concrete at Various c/w and

\begin{tabular}{ccc}
\multicolumn{3}{c}{$r / w$} \\
\hline $\mathrm{c} / \mathrm{w}$ & $\mathrm{r} / \mathrm{w}$ & Compressive strength $\left(\mathrm{f}_{\mathrm{cu}}\right) \mathrm{N} / \mathrm{mm}^{2}$ \\
\hline 2.37 & 0.13 & 27.37 \\
2.11 & 0.11 & 24.73 \\
1.9 & 0.1 & 26.39 \\
1.73 & 0.09 & 30.00 \\
1.58 & 0.08 & 24.15 \\
2.25 & 0.25 & 13.24 \\
2.0 & 0.22 & 23.25 \\
1.8 & 0.2 & 34.04 \\
1.64 & 0.18 & 27.73 \\
1.5 & 0.17 & 23.64 \\
2.13 & 0.38 & 6.75 \\
1.89 & 0.33 & 16.84 \\
1.7 & 0.30 & 28.45 \\
1.55 & 0.24 & 30.98 \\
1.42 & 0.25 & 20.49 \\
2.00 & 0.50 & 5.50 \\
1.78 & 0.44 & 12.41 \\
1.6 & 0.4 & 22.14 \\
1.45 & 0.36 & 21.74 \\
1.33 & 0.33 & 22.39 \\
1.87 & 0.63 & 5.59 \\
1.67 & 0.56 & 8.93 \\
1.5 & 0.50 & 18.97 \\
1.36 & 0.46 & 12.32 \\
1.25 & 0.42 & 17.32 \\
1.75 & 0.75 & 3.77 \\
1.56 & 0.67 & 6.82 \\
1.40 & 0.6 & 13.72 \\
1.27 & 0.55 & 8.04 \\
1.17 & 0.5 & 12.00 \\
& &
\end{tabular}

Table 7: Coefficients of the Equation and their P Values

\begin{tabular}{lccl}
\hline Independent variables & Coefficient & $P$ values & Significant level \\
\hline Constant & 45.206 & $1.95 \times 10^{-8}$ & Very significant \\
$\mathrm{c} / \mathrm{w}$ & -7.026 & 0.024 & Very significant \\
$\mathrm{r} / \mathrm{w}$ & -42.5 & $1.47 \times 10^{-9}$ & Very significant \\
\hline
\end{tabular}

3.6 Diagnostic Plots of the Residuals

Several graphical plots were obtained to show the capability of the fitted linear model. Figures 2 and 3 show the scattered plots of the compressive strength against $\mathrm{r} / \mathrm{w}$ ratio and $\mathrm{c} / \mathrm{w}$ 
ratios respectively. The experimental points are scattered about the mean residual value of zero (0). This is an indication of a good model.

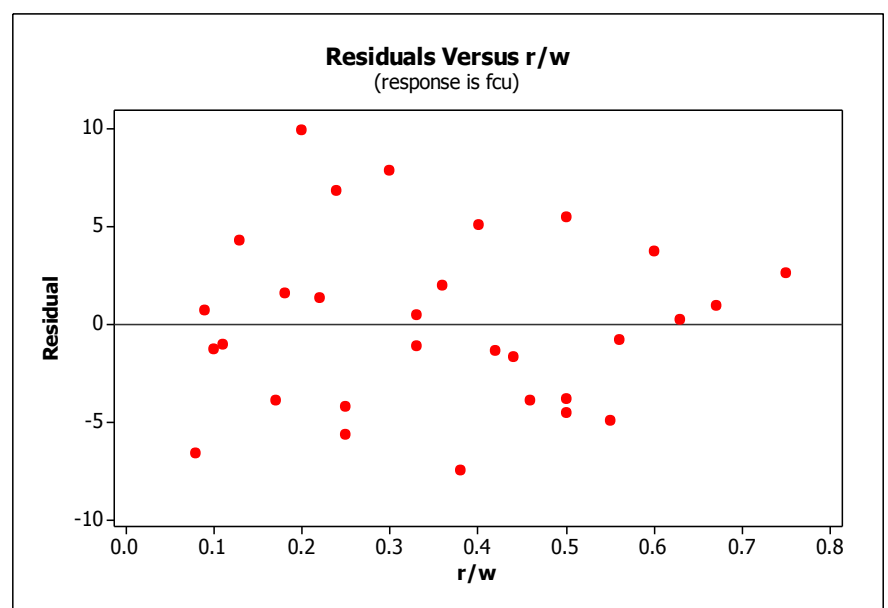

Figure 2: Scatter Diagram of $f_{c u}$ Residual Versus $r / w$

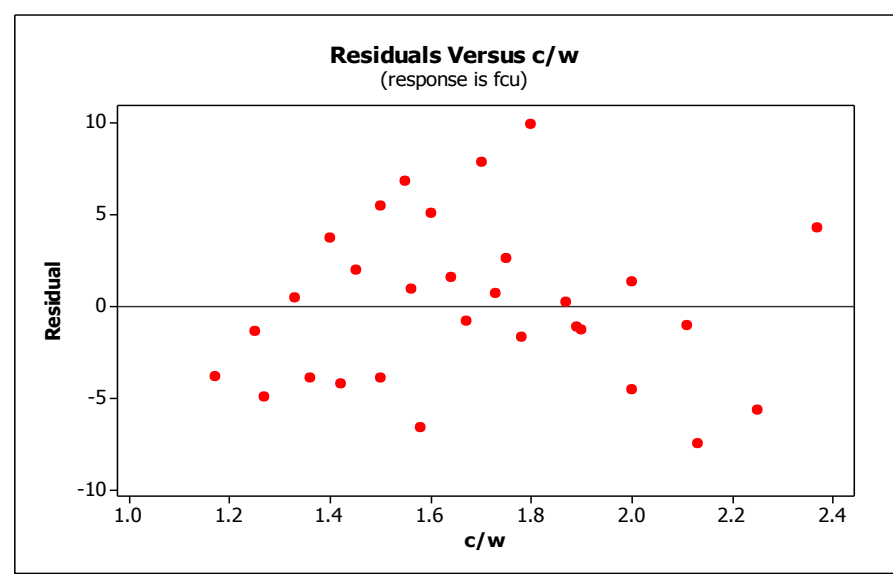

Figure 3: Scatter Diagram of $f_{c u}$ Residual Versus $c / w$

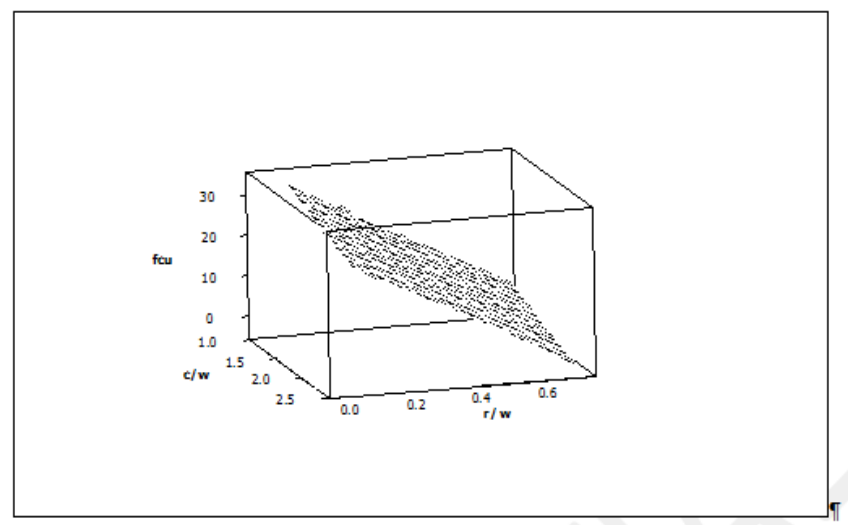

Figure 4 Surface Plot of $f_{c u}$ vs $r / w, c / w$

\subsection{Surface Plot of the Linear Polynomial Model.}

Figure 4 shows the surface plot of the developed linear model. It gives the pictorial view of the behaviour of the underlying relationship. The plot shows a steeper slope for $\mathrm{r} / \mathrm{w}$ ratio compared to c/w ratio. This is also evident from Equation 18. This implies that $r / w$ ratio have significantly negative influence the compressive strength of concrete compared to $\mathrm{c} / \mathrm{w}$ ratio. Equation 18 has positive constant term and the variables $\mathrm{c} / \mathrm{w}$ and $\mathrm{r} / \mathrm{w}$ ratios have negative slopes. This implies that increase in the value of any of the variable will lead to a decrease in the corresponding values of the compressive strength.

\section{CONCLUSION}

From the outcome of this work, the following conclusions can be deduced:

a) The rice husk ash obtained belongs to Class F Pozzolana and is pozzolanic since the sum of the percentage of silica, alumina and ferric oxide above $70 \%$.

b) The range of the best water/binder ratio was found to lie between 0.50 and 0.55 as the concrete was very workable at this $\mathrm{w} / \mathrm{b}$ ratio for the replacement of cement with RHA after $15 \%$.

c) The experimental data was fitted into the hypothetical model with the line of best fit obtained from the model given as $\mathrm{f}_{\mathrm{cu}}=-7.026 \frac{c}{w}-42.467 \frac{r}{w}+45.305$

d) The compressive strength of hardened RHA concrete depends on cement-water $(\mathrm{c} / \mathrm{w})$ content and rice husk RHA - water $(r / w)$ content.

\section{REFERENCES}

[1] Rao, P. P., Kumaar, A. P. and Singh B. B. "A Study on Use of Rice Husk Ash in Concrete", International Journal of Education and Applied Sciences, Vol. 4, Number 2, pp 7581. 2014.

[2] Macginley, T. J. and Choo, B. S. Reinforced Concrete; Design Theory and Examples, E. and F. N. Spon, Chapman and Hall. London, 1990.

[3] Mosley, J. H. and Bungey, J. H. Reinforced Concrete Design, Macmillan Press, London, 1991.

[4] Edeh, J. E., Samson, I. and Terhemba, A. "Rice-Husk AshCarbide-Waste Stabilisation of Reclaimed Asphalt Pavement", Nigerian Journal of Technology, Vol. 35, Number 3, pp 465-472. 2016, [5] Okonkwo, U. N. and Agunwamba, J. C. "Classical Optimisation of Bagasse Ash Content-Stabilised Lateritic Soil". Nigerian Journal of Technology, Vol. 35, Number 3, pp 481-490. 2016,.

[6] Ndububa, E. E., Okonkwo, J. S. And Ndububa, O. I. "The Potential Use of Fonio Husk Ash as Pozzolana in Concrete". Nigerian Journal of Technology, Vol. 35, Number 1, pp 31-36. 2016.

[7] Akeke, G. A., Ephraim, M. E. and Ukpata, J. O.“Compressive Strength of Concrete With Rice Husk as Partial Replacement of Ordinary Portland Cement", Scholarly Journal of Engineering Research, Vol. 1, Number 2, pp 32-36 2012.

[8] Reddy, B. D., Jyothy, A. and Reddy, I. V. R. “.Effect of Rice Husk Ash on The Properties of Ordinary Portland Cement and Portland Slag Cement with and Without Super plasticizers", .International Journal of Civil, Structural, Environmental and Infrastructure Engineering Research and Development, Vol. 3, Number 2, pp 1-8. 2013. 
[9] Neville, A. M. Properties of Concrete, Longman Scientific and Technical Publishing, London, 1995.

[10] Popovic, S. Strength and Related Properties of Concrete: A Quantitative Approach, John Wiley and Sons, London, 1998.

[11] Hedegaard, S. E. and Hansen, T. C., "Modified Water Cement Ratio Law for Compressive Strength of Fly Ash Concrete", Materials and Structures, Vol. 25, pp 278-283. 1992.

[12] BS 3148 "Methods of Test for Water for Making Concrete", British Standard Institution, Her Majesty Stationary office London, 1980

[13] BS 4550: Part 2. "Chemical Test", British Standard Institution, Her Majesty Stationary office London, 1978.

[14] ACI Committee 211.1-91.“Standard Practice for Selecting Proportions for Normal, Heavyweight and Mass Concrete", Detroit, American Concrete Institute.

[15] BS 1881: Part 102."Method for Determination of Slump of Fresh Concrete", British Standard Institution, Her Majesty Stationary office London, 1983.

[16] BS 1881: Part 116. “Method for Determining Compressive Strength of Concrete Cubes", British Standard Institution, Her Majesty Stationary office London, 1983.

[17] Oyetola, E. B and Abdullahi, M. "The Use of Rice Husk Ash in Low-Cost Sandcrete Block Production", Leonardo Electronics Journal of Practices and Technology, Vol. 8, pp 58-70. 2004.
[18] oaquim, S., Coutinho, J. S. and Sampaio, M. N. Portuguese Rice Husk Ash as Portland cements Replacement. U.S. Patent no 5329867, 1994.

[19] Habeeb, A. G. and Mahmud, B. H. "Study on Properties of Rice Husk Ash and Its Use as Cement Replacement Material", Journal of Material Research, Vol. 13, Number 2, pp 185-190.2010.

[20] ASTM- American Society for Testing and Materials C 618 "Standard Specification for Coal, Fly Ash and Raw or Calcined Natural Pozzolan for Use in Concrete". .4 (04), 1994.

[21] Ogunbode, E., Hassan, I. O., and Isa, R. B. "An Evaluation of Compressive Strength of Concrete made with Rice Husk Ash obtained by Open Air Burning", Environmental Technology and Science Journal, Vol. 4, Number 1, 2011, pp 137-147.

[22] Dabai, M. U., Muhammad, C., Bagudo, B. U. and Musa, A. "Studies on the Effect of Rice Husk Ash as Cement Admixtures", .Nigerian Journal of Basic and Applied Science. Vol. 17, Number 2, pp 252-256. 2009.

[23] Akeke, G. A, Ephraim, M. E, Akobo, I. Z. S, and Ukpata, J. O. "Structural Properties of Rice Husk Ash Concrete", .International Journal of Engineering and Applied Sciences. Vol. 3, Number 3, pp 57-62. 2013,

[24] Reynolds, E. C. and Steedman, C. J. Reinforced Concrete Designers Handbook. Spon Press, Taylor and Francis Group London, 1988. 